Discourse and Communication for Sustainable Education, vol. 8, no. 2, pp. 77-93, 2017

\title{
Effects of Contextual Factors on ESD in Teacher Education
}

\author{
Çağla Atmaca \\ Pamukkale University, Turkey
}

\begin{abstract}
Education for sustainable development (ESD) guides and empowers educators to reshape their thinking style and move towards a sustainable future. It has attracted a lot of attention and been studied in different perspectives. However, contextual factors have not been studied in relation to sustainable development for teacher education. Therefore, this study aims to find out the possible effects of changing contextual factors on preservice and in-service teachers in terms of sustainable education for their profession. For this purpose, 267 pre-service teachers from four different universities and 50 inservice teachers from 15 different cities participated in the study. Out of 317 participants, 245 stated that contextual factors influence their teaching habits adversely, while 54 reported that they ignored the outer factors. In light of the data gathered, it can be said that the participant teachers were mostly pessimistic about the effect of contextual differences on ESD. Based upon participant statements, a new theory emerged. According to this theory, there are personal $(\mathrm{P})$, institutional $(\mathrm{I})$, stakeholder-related $(\mathrm{S})$, environmental (E) and training-related (T) factors which positively and/or negatively influence ESD in teacher education. In this regard, the new theory was formed with the first letters of the related factors and called P.I.S.E.T. These findings suggest that pre-service teachers should be exposed to various school settings during their practicum and inservice teachers should receive context-related support from the stakeholders to enhance their professional skills and act in line with the principles of ESD.
\end{abstract}

Keywords: Teacher education, contextual factor; student teachers; in-service teachers; sustainability; sustainability education.

\section{Introduction}

Different school settings like rural, suburban, and urban take an important role in the formation of self-efficacy beliefs of student teachers since the student teacher is expected to adapt to the environment and develop coping strategies accordingly. With the participation of 102 student teachers in rural, suburban, and urban settings, Knoblauch and Hoy (2008) found that while all the participants' self-efficacy levels increased, urban student teachers showed significantly lower perceived collective efficacy. 
The effect of contextual factors on teaching practices and professional sustainability of teachers needs to be questioned more closely to respond to real needs of teachers and prepare them in line with the requirements. What is more, the perspectives of pre-service and in-service teachers should be compared to detect the mismatch if there exists any and redesign the teacher education models more appropriately. Therefore, this study aims to find out the opinions of teachers about the effect of contextual factors on their teaching practices and professional sustainability, and compare the views of pre-service and in-service teachers to contribute to the understanding of a theory-practice gap in different school settings.

\section{Literature Review}

\section{Contextual Factors in Teacher Education}

The underlying reason to prioritize contextual factors lies in the fact that especially beginning teachers may easily get discouraged during their first year due to hardships and adaptation problems. For example, beginning special education teachers reported problems related to insufficient curricular materials, dealing with behavior management/ discipline, and obstacles to collaboration frequently (Kilgore, Griffin, Otis-Wilborn \& Winn, 2003).

Based upon the reflections of pre-service and in-service teachers, policy makers could make changes in the structure of teacher education programmes. With the participation of 1147 teachers completing the questionnaires, it was found that the teachers stating to be well-prepared in advance to cope with the first year of teaching were those who had taken courses related to content, methodology, planning and assessment (Ingvarson, Beavis \& Kleinhenz, 2007). Therefore, reflections of pre-service and in-service teachers deserve closer attention in policy management and implementation in terms of teaching standards so that previous beliefs and practical realities of teachers do not clash in the classroom when they meet students.

The need to refer to the effect of contextual factors within teacher education is a highlighted aspect in research on teacher education undertaken by Grossman and McDonald (2008). School climate including such elements as parent/community relations, administration, student's behavioral values was found to be related to emotional exhaustion, depersonalization, and feelings of low personal accomplishment, which cause burnout for all together. In addition, it was revealed by Grayson and Alvarez (2008) that the inverse relationship between school climate and burnout was mediated by teacher satisfaction levels for both emotional exhaustion and depersonalization dimensions.

The role of contextual factors is of great importance for further educational actions since what will be done will be determined according to what is needed on the basis of what has been done. Teachers' practical experiences can be employed as the starting point for further actions. In other words, teachers' suggestions and criticism should be taken into consideration while making educational decisions. Basing the educational decisions and policies on the classroom data coming from the concrete experiences of teachers and administrators could be productive in the long term in order to set more realistic goals and fulfil these goals appropriately. Schildkamp and Kuiper (2010) touched upon the positive effects of using classroom level data by teachers for educational decisions and school level data by school directors for educational policies in the Netherlands. 
Reflections of pre-service teachers are important since they begin to shape their beliefs and practices in parallel with the theoretical knowledge and practical applications gained at university before graduation and certain personal, professional and contextual aspects encountered during pre-service teacher education programmes could be influential on their further teaching practices (Naylor, Campbell-Evans \& Maloney, 2015). The school environment affects not only student motivation but also teacher motivation. Positive and encouraging contextual variables have the potential to positively contribute to the teacher's professional development while unfavourable contextual variables hinder improvement and damage motivation. The first years of teaching career are crucial for the long-term retention of teachers so new teachers should be under close scrutiny to detect their real needs and provide an in-service training appropriately. With the participation of 589 beginning French-Canadian teachers working at elementary and high schools, it was found that school environment factors such as work overload, control, recognition, and sense of community affect teachers' emotional exhaustion and their attitudes towards teaching profession (Fernet, Trépanier, Austin, \& Levesque-Côté, 2016).

\section{Sustainable Development in Teacher Education}

Teacher education is a complex and multi-dimensional field which necessitates the participation of various stakeholders. Among these, academicians or in other words teacher educators play an important role for teacher candidates. With the courses they deliver, they become either a good model or a bad model for their students so that teacher candidates reach a synthesis about what to become and what not to become when they graduate and become an in-service teacher. Thus, it can be said that teacher educators' habits influence student teachers' preferences to some extent. In this sense, Aslandağ Soylu, Yanpar Yelken and Külekci (2016) conducted a study on 211 teacher educators in Turkey and examined their lifewide learning habits which are included under the umbrella term of sustainable development. The participant teacher educators' lifewide learning habits were found to be at a high level based on their mean scores $(135,27)$ with regard to six dimensions: problem solving habits, professional development, cultural interaction habits, leadership habits, care-based habits and leisure habits. They were suggested to deepen their students' interest in such habits and popularise these habits via various activities among student teachers in order to contribute to their personal and professional development.

Since each educational setting is highly contextual, stakeholders have different expectations from teachers and the changing nature of schools pushes teachers to act in line with these expectations In this respect, preparedness of the teacher for the sociocultural structure of environment and school climate comes to the fore, which raises the question whether teachers are raised as culturally responsive (Iliško, 2007; Salìte, 2015). In this regard, Williams, Edwards, and Kuhel (2016) questioned the states of five mathematics teachers who teach in a multicultural school setting. They stressed the role of the enhanced program they were involved in and demonstrated the importance of teacher preparedness and competencies for professional sustainability of their teaching career.

Education for sustainable development (ESD) is still a hot issue which troubles teacher education programs. After analysing the content of science course books in 
Turkey, Sahin (2016) reached the conclusion that interdependence, citizenship and stewardship, needs and rights of future generations, diversity, quality of life, equity and justice, sustainable change, and uncertainty and precaution in action are the core aspects of ESD and the related science course books do not cover the emergent core aspects. As an alternative, Pipere (2016) suggests the inclusion of the cognitive approaches of a hermeneutical cycle to make a clear definition of ESD and remove the blurring of its meaning. In a similar vein, teacher candidates can be taught to possess hermeneutical thinking features and apply them in their teaching practices to ensure effective application of ESD and contribute to their professional identity.

Stakeholders play a crucial role to ensure the quality of teacher education programs and continue sustainability for professional aims. Since sustainability is a tool of continuous progression, it is important to reveal and compare the opinions of different groups of stakeholders who have a say and shape the content and route of teacher education programs. Likewise, Gholami and Qurbanzada (2016) examined the perspectives of 62 pre-service teachers, 48 in-service teachers, and 28 teacher educators in Iranian context at TEFL (Teaching English as Foreign Language) departments. What was stressed by all the three groups of participants was the existence of practical courses such as methodology in TEFL program and courses like practicum and classroom observations were reported to empower teachers for real educational settings. The strong emphasis on practical courses could stem from the fact that complexities of classrooms and dynamics of students are best understood with the help of practical courses where student teachers are met with the real teaching itself aside from the introduction to the changing expectations of the other stakeholders. Therefore, inclusion of more quantified and qualified practical courses is seen as a useful tool for enhancing sustainability in teacher education programs via the participation of various stakeholders.

University students' beliefs are considered important in terms of ESD because what they believe reveals valuable cues in understanding what needs to be done to ensure effective implementation and how to adapt existing curriculum to serve the key principles of ESD. To exemplify Ates, Teksöz and Ertepinar (2017) focused the perspectives of students receiving education at METU (Middle East Technical University) in Turkey about global climate change and found out that ecocentric attitude and perceived knowledge were the primary factors which impact their views. Moreover, teachers are expected to update themselves in line with the changing needs of the era and technological advances are no exception. In this regard, teachers are required to possess technological skills and competencies in order to deliver their courses with various materials including technological tools like computers, smart boards and/or projectors. Teachers' competencies determine their route for professional sustainability and educational development because as a stakeholder influenced by the principles of ESD, teachers contribute to educational sustainability in their work places (Çoklar \& Kabakçı Yurdakul, 2017).

Sustainable development has got eight main features which require competencies in foresighted thinking, interdisciplinary work, transcultural understanding, participatory skills, planning, compassion, self-motivation and reflection (de Haan, 2006; Barth, Godemann, Rieckmann, \& Stoltenberg, 2007). Since teacher training programs have a crucial role to enhance professional skills, it is inevitable for higher education institutions to integrate these competencies across the curriculum. Only in this way can student teachers gain consciousness about how to develop their personal competencies in the long term 
and thus have lifelong learning skills. In a similar vein, Hiller and Reichart (2017) revealed the low level of self-efficacy of teachers-in-training with regard to sustainable development and highlighted the role of motivation and interest in sustaining their competencies regarding ESD.

In light of the relevant literature, it is seen that ESD has expanded to include various fields and teacher education is no exception. Although there exist studies about science teacher education or maths teacher education, ESD seems to be an overlooked area in foreign language teacher education. Thus, this study aims to answer the following research questions:

1. What do the participant teachers think about the effect of contextual factors like administrative support, physical conditions, and size of classes on their preferred teaching practices?

2. Are there any differences between the participant pre-service and in-service teachers in terms of their opinions about the effect of contextual factors on their preferred teaching practices?

\section{Methodology}

\section{Research Design}

This study aims to find out and compare the opinions of pre-service and in-service teachers regarding their perspectives about the effect of contextual differences on their preferred teaching practices and professional sustainability and offer some solutions. The study adopted a descriptive research design since the aim is to explain the phenomenon in question. In the study, the participants attach meaning to the study depending on their contexts by giving concrete examples based on their experiences (Maxwell, 1992). Descriptive research has the characteristics of providing a picture of a situation as it takes place in its natural environment (Burns \& Grove, 2003, p. 201).

\section{Participants}

The study includes pre-service teachers and in-service teachers who actively work at various types of state schools. The pre-service teachers were chosen since they were thought to have taken the necessary theoretical and practical courses and graduate soon. Moreover, they took school experience courses in the first term of the fourth year in which they visited state schools regularly and made observations on both students and teachers. In the second term of the last year, they undertook a practicum where they were required to deliver courses under the custody of the mentor teacher who was observed in the previous term. They were checked and given feedback by both the mentor teacher at school and the advisor at university, which was an application done to strengthen the link between theory and practice, and contribute to university-school collaboration. Since the study was conducted in the second term of the academic year, that is, in spring term in April-May in 2015, the pre-service participants were thought to have mastered the theoretical background of teaching and been exposed to real educational settings and real students to teach. The participant pre-service teachers were thought to truly reflect characteristics of a student and a teacher since they were in between being a student and a teacher at the same time so their insights upon their education and practices will 
reflect the delicacies of teaching in a real context and the changes they undergo. In this regard, purposed sampling was adopted by the researcher. It reached to a larger number of participants via qualitative means and was aimed to get a deeper understanding about the phenomenon in question although such a choice was demanding and time-consuming on the part of the researcher. The pre-service teachers who were receiving education at the faculties of education were chosen from four different state universities, which was done to increase the representativeness of the sample. As to the in-service teachers, they were chosen in different cities which were categorized as third-level cities according to the statistical institute of the country for categorizing the cities in different regions according to their economic and developmental features, which was again done to collect data from different parts of the country and increase the representativeness of the sample. The participant in-service teachers were working at various state schools in 15 different cities. The sample of the study consists of 267 pre-service teachers studying at four different state universities and 50 in-service teachers working in 15 different cities. In total, 317 teachers participated in the study.

\section{Research Method}

Since the study is concerned with the perspectives of the participants upon a specific action, the researcher adopted qualitative research method in order to get detailed answers from the participants (Dörnyei, 2007) and compared the opinions of pre-service and inservice teachers with the help of their written comments so that it will be found out whether any mismatch exists between the two groups of the participants, what kind of problems occur in practice and what can be done to remove these challenges to reach national and international standards in terms of teacher education. However, the researcher felt the need to refer numerical data in the form of frequency and percentage tables while showing the participant comments in order to benefit from the complementary purposes of numbers (numerical data in form of descriptive statistics) and words (qualitative data), and provide a more understandable and clear framework on the part of the reader (Creswell, Plano Clark, Gutmann, \& Hanson, 2003). Combining words and numbers will provide the reader with the opportunities to get a better understanding about the phenomenon in question and validate research since the words and numbers witness each other and reinforce comprehension in this way (Strauss \& Corbin, 1998). In other words, qualitative data are quantified and quantitative data are qualified. That is why frequency and percentage tables are followed by the participant quotations.

\section{Data Collection Tool}

A written interview form was prepared by the researcher based on the focus of the articles related to teacher induction and teacher competencies, and sent in to 6 associate professors at the faculties of education in the related country to get expert opinions for the sake of ensuring the validity and reliability of the form. The experts gave feedback on the content and layout of the form, which required some revisions. The researcher took all the revisions required into account and made some modifications in the form to conform to the rules of validity and reliability. After the revisions, the form was sent back to the experts to get confirmation until there was a complete agreement among 
them. Although the form was evaluated separately, the revised form was sent to all and their final views on the form were gathered. After the form gained its final shape on the basis of the feedback and last minor revisions, the researcher started to apply it to examine the perspectives of student teachers and in-service teachers. The form consists of two parts including one part to get demographic information and another part for the interview items (consisting of yes/no questions and open-ended questions) regarding the effect of contextual factors on teachers' preferred teaching practices. Some participants suggested solutions in their statements in the last interview item.

\section{Data Analysis Tool}

Qualitative data analysis procedures were employed due to the qualitative nature of the study. First of all, participant comments were coded on the computer and each participant was given a number to ensure anonymity of the participants and get more detailed and reliable answers from them. Then, the answers were read and categorized by the researcher and another separate coder and emerging themes were identified. The coders moved back and forth following a zigzag pattern (Dörnyei, 2007) while analysing the data since they always made comparisons among the statements by looking at previous and next statements. Thus, the constant comparison method of grounded theory (Glaser \& Strauss, 1980) was used in the study since the coders also paid attention to the emerging categories to be general, understandable, easy to practice, flexible, and in harmony with social beliefs, everyday life realities and changing facts. Such a data-driven approach was adopted in order to get a framework from emerging themes. However, the researcher relied on Informed Grounded Theory proposed by Thornberg (2012), who criticised delaying review of literature and went for analysis after getting the related literature in order not to miss any important point or end up with unnecessary items at the end of analysis procedures. In a similar vein, the researcher was first concerned with the review of literature and then began to analyse participant comments. When the researcher completed analyses, she revised the previously formed categories and themes after about three weeks and made some changes to ensure intra-rater reliability. A second and independent coder was also involved in the data analyses and came up with his/her own categories and themes. After the $25 \%$ of the data were analysed, the two coders held a meeting and compared their categories and themes to ensure inter-rater reliability according to inter-rater reliability formula proposed by Miles and Huberman (1994, p. 64). In the first meeting, the agreement level between the coders was calculated

to be $85 \%$. Excel programme was also utilized during the coding and categorization of the data - the number of the teachers representing the order of participation was easily determined and the disagreed statements which were interpreted and categorized differently by the coders were easily detected and highlighted for further analysis. The two coders discussed the different codes and decided to analyse the disagreed codes again. In the second meeting, the agreement level went up to $93 \%$ according to the inter-rater reliability formula. In the second meeting, the two coders went on analysing the different codes until there was complete agreement. 


\section{Findings}

First of all, the tables summarizing the categories and emerging themes will be given. The quotations belonging to pre-service and in-service teachers are then provided to exemplify the related category and make comparisons between the participants.

\section{Opinions on Contextual Factor's Effect}

Participants' opinions about the effect of contextual factors on teaching practices are given in Table 1 below.

Table 1

Opinions on Contextual Factors' Effect

\begin{tabular}{lcccc}
\hline Category & Pre-service & In-service & Total $(\mathrm{F})$ & Percentage $(\%)$ \\
\hline Positive & 196 & 49 & 245 & $77.2 \%$ \\
\hline Negative & 54 & 0 & 54 & $17.1 \%$ \\
\hline Suspicion & 2 & 0 & 2 & $0.7 \%$ \\
\hline Mixed & 6 & 1 & 7 & $2.2 \%$ \\
\hline Irrelevant & 9 & 0 & 9 & $2.8 \%$ \\
\hline Total & 267 & 50 & 317 & $100 \%$ \\
\hline
\end{tabular}

According to Table 1, five different categories emerged. The first category (positive) means that the participant agreed that contextual factors hinder their preferred teaching practices while the second category (negative) means that the participant ignores the contextual factors. The third category (suspicion) means that the participant is suspicious about the contextual factors' effect and finally, the last category means the participant holds mixed opinions about the phenomenon in question in that he has both positive and negative opinions about it. A small number of participants gave irrelevant answers to the questions so they were excluded from the scope of the study and not taken into consideration in further analyses.

Table 1 shows that a high majority of the participant teachers (F: 245, 77.2\%) think that contextual factors such as administrative support, physical conditions, and crowded classes affect their preferred teaching practices adversely. This is followed by the participants (F: 54, 17.1\%) who disagree with the adverse affects of contextual factors and think that a teacher can ignore outer factors and overcome difficulties with his/her teaching knowledge, skills and competencies based on previous learning and/ or teaching experiences. The participants with mixed opinions (F: 7, 2.2\%) come in the third place. They are the ones who have both positive and negative opinions about the effect of contextual factors. Finally, the participants who are suspicious (F: 2, 0.7\%) are in the last place and they are the ones who approach the phenomenon in question with suspicion.

When the details of the table are examined, it is seen that there exist both similarities and differences between the pre-service and in-service teachers. A high majority of the pre-service participants (F: 196, 73,4\%) were found to be in favour of the changing effects of contextual factors. In a similar vein, almost all of the in-service teachers (F: 49, $98 \%$ ) were found to be under the negative influence of contextual factors. It is seen that the participants who are in favour of the adverse effects of contextual factors come first in both groups. However, there are differences in terms of ignoring the outer factors in 
teaching practices. Although $54(20.2 \%)$ pre-service teachers stated that they could ignore contextual factors and would not let these factors hinder their preferred teaching practices, there were no in-service teachers who think so. Besides, there were no in-service teachers who are suspicious about the effect of contextual factors, although there are two suspicious pre-service teachers. The number of participants with mixed opinions about the effect of contextual factors (including both positive and negative opinions) also differs in both groups in that there are six $(2.2 \%)$ pre-service participants with mixed opinions whereas there is only one $(2 \%)$ in-service participant with mixed opinions. However, the percentage is very close in that it is $2.2 \%$ for pre-service teachers while it is $2 \%$ for in-service teachers. Finally, all irrelevant answers belong to pre-service participants (F: 9, 3.3\%) while there is no in-service participant with irrelevant answers.

\section{Participant Quotations about Contextual Factors}

Most of the participants (196 pre-service and 49 in-service teachers) fall on the category of positive because they think that contextual factors deeply affect and hinder their preferred teaching practices. Below are some sample quotations of pre-service participants.

STE 16: Absolutely everything affects our class conditions like environment, family, friendships.

STE16 thinks that there are many context-bound differences that could affect their performance and that range from the physical environment to related stakeholders.

STE 67: Yes, support and physical conditions are important. I can't create all opportunities myself.

STE67 highlights the importance of administrative support and physical appearance in educational settings and adds his/her limitations to overcome some difficulties.

STE 71: Of course, it will. In university, we work with our friends or small classes, in a crowded class. I will have lots of problems, such as classroom management.

STE71 mentions lack of a real classroom environment to apply teaching and probable negative consequences in terms of classroom management.

STE 84: Absolutely, because of these problems, even in practicum we have difficulty in our classes the presentation we make in university classes won't work in real MEB classes. When I look at the views of teachers on the internet, there are lots of complaints about conditions.

STE84 seems to be negatively affected by the views of teachers working at state schools and talks about the university-school gap.

STE 97: Yes. I think traditional and strict administrative attitudes, bad physical conditions and crowd of classes will prevent my innovative techniques. 
According to STE 97, administrative attitudes, physical conditions and the crowded classes are the main factors affecting their new and original teaching practices.

STE 165: Due to being exams always, I think I will not be able to what I will want to do. The students will want to do the things that help them in the exams. For example; communicative activities are ignored, then why are we bad at speaking?

According to student teachers, both physical conditions and stakeholder attitudes could influence their teaching style. While some report that anything could affect their teaching practices, others stress specific aspects like crowded classes, lack of stakeholder support, artificial teaching practices and the washback effect of high-stake examinations.

Below are some examples of in-service teachers' quotations.

T 368: Yes, of course. For instance, last Semester I planned to teach the topic of the traffic signs. But my class condition is not appropriate for the TPR.

$\mathrm{T}$ 370: The most important is physical conditions. We have to do something special to maintain and change the class.

T 375: Yes, of course. If it is too cold in winter and there are over 40 students in the classes, how can we be effective?

The first three teachers touch upon the importance of the physical conditions within the classrooms, climate issues and the large crowded classes since these factors are considered to be hindering their preferred teaching practices.

T 406: Yes, sure. As teachers we feel anxious about the curriculum that we have to finish by the end of the year. Authorities may sometimes criticize for not following the curriculum. As they are not competent teachers in language teaching they sometimes criticize insensibly. What's more we are lack of technology and materials. It's not always easy to prepare our own materials for crowded classrooms all the time as they cost much. So, it would be beneficial to increase the number of the lessons at schools and reduce the intensiveness of the curriculum and to provide teachers enough opportunities to afford good materials.

The in-service teachers tend to give more concrete examples due to their practical involvement in teaching. Some teachers complain about the seating arrangement, large cohorts of students, and classroom size due to their limiting impact. The last participant mentions the burden of curriculum coverage and negative attitudes of inspectors. S/he also talks about the negative effects of the lack of materials.

In sum, emerging themes in the positive category include environment, family, friendships, reducing teacher motivation, lack of language labs, discipline problems, lack of student motivation, the mood of students, effect of different ethnic communities, lack of technological tools, physical environment, technological tools, curriculum constraints and time limitations, lack of materials, cultural differences, crowded classes, lack of administration support, classroom management, lack of real practical experience, fixed course-book and syllabus, obligation to covering the curriculum, high-stake exam, central educational policy, parent's interruption, lack of student interest, insufficient 
infrastructure, administrative deficiencies, regulations, time limitation, climate issues (like hot and cold) and ineffective inspection practices.

In contrast to these participants, some other participants prioritise the existence of teacher over the contextual factors and suggest the ways of coping with uncertainty.

STE 60: No, I think there is nothing that can prevent me from teaching perfectly. No matter how crowded the classes are there is always a chance to handle with that class.

STE 62: I don't believe that the crowd of classes and physical conditions affect the teacher. The teacher has to do best in any conditions.

STE 92: I don't think so I can manage the classroom with the help of methods I learned.

The first three student teachers seem to disregard the effects of contextual factors and even turn these differences into advantages to teach in a unique way. The ability to make use of teaching methods and professional knowledge is underlined for its facilitating role in classroom management.

STE 237: No, because I will be try to be a flexible teacher and I will have a "B” plan.

STE 292: I think if one wants to do something, there aren't anything to hinder him to manage his goods or objectives. But conditions should be improved, especially in learning classes.

These student teachers think that nothing can prevent the teacher from doing the desired activities within the classroom and the teacher has to have another plan in case of unexpected situations. Thus, these statements were grouped under the category of negative. Such participants seem to disregard outer factors and rely on self-skills and knowledge to cope with difficulties, which indicates the importance of teacher selfefficacy for demolishing the contextual hardships.

As for the statements of in-service teachers, there are no participants who think that contextual factors cannot hinder them from applying what they actually would like to do in their classes.

When the themes of negative category are examined, it is seen that the participant teachers focused on interaction with stakeholders, personal qualities, teaching competencies, content and pedagogy-related knowledge and professional skills to disregard outer factors in implementing their preferred teaching activities.

A small number of pre-service participants were suspicious about the effect of contextual factors on their teaching practices and made statements that show their indecision.

STE 90: Maybe I don't know but time shows us the reality.

STE 277: Maybe yes.

Although there were two statements revealing suspicion among student teachers, there were no examples of suspicion in the statement of in-service teachers.

The last category includes participants with mixed opinions towards the effects of contextual factors, that is, statements displaying both positive and negative opinions about contextual factors or statements with conditional clauses. First, student teacher responses are presented below. 
STE 102: Disadvantage - irresponsible administrators, lack of money, and opportunities, irrelevant parents. Advantage - cooperation and experience

STE 178: I don't know it changes to my students. Wait and see J

STE 291: Yes, of course. There are a lot of factors that affect it. Positive or negative way.

STE 361: Yes, if all of the situations were good enough, objectives will become very easy to apply.

STE 366: Maybe in some ways it can be a handicap for my profession.

While some student teachers see contextual factor differences both as an advantage and a disadvantage due to the unexpected positive or negative effects, others point out the role of student characteristics and retarding result of contextual factors in terms of course aims. Administration, financial issues, parental involvement and student characteristics are counted as factors that may function either as a disadvantage or an advantage.

Only one in-service teacher held a mixed opinion as follows.

T 376: Sometimes. Maybe.

S/he does not think that contextual factors are always an obstacle. Rather, they are sometimes treated as hindering factors.

\section{P.I.S.E.T. Theory}

In light of the data gathered about the opinions of the participants, a new theory called P.I.S.E.T. was formed regarding the contextual factors affecting ESD in teacher education. At the end of the procedures of constant comparison method included in grounded theory, five main categories emerged. According to P.I.S.E.T. theory, there are personal, institutional, stakeholder-related, environmental and training-related factors which positively and/or negatively influence ESD in teacher education as indicated in Table 2 below.

Table 2

P.I.S.E.T. Theory: Components of Contextual Factors Affecting ESD

\begin{tabular}{ll}
\hline Personal Factors & motivation, self-sources, methods-approaches, flexibility, B plan, \\
& $\begin{array}{l}\text { link with stakeholders, personal qualities, teaching competencies, } \\
\text { content knowledge, pedagogy knowledge, professional skills, } \\
\text { cooperation skills, teaching experiences }\end{array}$ \\
\hline Institutional Factors & $\begin{array}{l}\text { physical conditions, lack of language labs, school climate, lack of } \\
\text { technological tools, curriculum constraints, time limitations, } \\
\text { crowded classes, lack of administration support, fixed course-book } \\
\text { and syllabus, obligation to covering the curriculum, high-stake } \\
\text { exam, central educational policy, insufficient infrastructure, } \\
\text { administrative deficiencies, regulations, lack of money }\end{array}$ \\
\hline Stakeholder-related & $\begin{array}{l}\text { family, friends, lack of student motivation, students' mood, parent's } \\
\text { interruption, lack of student interest, lack of English knowledge of }\end{array}$ \\
& inspectors, decisions of policy makers, learner characteristics (age, \\
& level, gender)
\end{tabular}


Sequel to Table 2.

\begin{tabular}{ll}
\hline $\begin{array}{l}\text { Environmental } \\
\text { Factors }\end{array}$ & $\begin{array}{l}\text { socio-economic structure, location, different ethnic communities, } \\
\text { cultural differences, climate issues (like hot and cold) }\end{array}$ \\
\hline Training-related & $\begin{array}{l}\text { discipline problems, no focus on ESD, lack of materials, lack of } \\
\text { Factors } \\
\text { establish authority upon learners), lack of real practical experience, } \\
\text { ineffective inspection practices, limitations of micro-teaching, lack of } \\
\text { money, lack of opportunities }\end{array}$ \\
\hline
\end{tabular}

Personal factors cover personal characteristics and professional competencies of teachers. A teacher's motivation, self-sources, professional competencies, interaction with stakeholders, content knowledge pedagogy knowledge, cooperation skills and previous teaching experiences were found to determine the degree of contextual factors' influences on promoting ESD in pre-service and in-service teacher training. The participant teachers were aware of the fact that their teaching knowledge and skills as well as interactive competencies will help them to overcome the difficulties or problems resulting from contextual factors. They stress that being equipped with teaching methods and techniques, they can have a flexible teaching and go on with a different plan in unexpected cases. They also highlight that all these personal factors will eventually lead to sustainable development in educational settings in spite of contextual factors.

Institutional factors include the physical and administrative traits of educational settings where teaching activities are actualised. Physical appearance of a school, classroom sizes and conditions, intense curriculum content, time limitations to cover the curriculum, crowded classes, administrative attitudes, fixed and compulsory course boks and syllabuses, washback effects of high-stake exams, insufficient infrastructure, regulations and lack of money were the commonly cited institutional factors which affect the enhancement of ESD. In Turkey, schools are given a stable curriculum and teachers are expected to cover the curriculum in the given time. In addition, students's success and scores in the high-stake exmainations are regarded as the teachers' and/ or schools' success. Thus, teachers feel pressured to prepare students in line with the content of these examinations. Other sub-factors are the crowd of the classrooms and insufficient physical conditions which could prevent implementation of comuunicative activities. Some schools may have budget problems and not renew themselves to serve teacher expectations. Such institutional factors were cited to be the obstacles in front of the effective application of ESD in educational settings.

Stakeholder-related factors consist of the people who both affect and are affected by the outcomes of educational activities. In this respect, stakeholders in education include students, teachers, parants, administrators, inspectors, policy makers, family, friends and colleagues. Student characteristics such as their age, language level, motivation, mood, gender and interest determine their participation. Inspectors are thought to be insufficient to observe and evaluate English teachers because of their lack of English knowledge, which is a highly criticized point by the participant in-service English teachers. Additionally, parental issues like their unreal expectations, lack of interest to cooperate with the teacher and attitiudes of school management play an important role in education for sustainable development. Another factor is the obligation to act according to the decisions of policy makers. It is seen that stakeholders shape the implementation of ESD to a large extent. Therefore, teacher participation in decision-making procedures 
at national and local level seems to be a key solution in fostering the principles of ESD at schools.

Environmental factors are concerned with the place that the educational institution is found in because schools are unavoidably affected by their environments. The school's socio-economic structure, location and climate issues have an impact upon teaching practices. For example, in some regions it is possible to come across different ethnic communities and when teachers face cultural differences, they may have difficulty in adapting to their new surrounding. Beasides, too hot or too cold weather may prevent or change teaching practices to some extent.

Finally, the last category is about training-related factors which specifically focus on the nature of pre-service and in-service teacher education programmes. Teachers displayed their dissatisfaction with the training they underdo in the course of time throughout their career and critise their lack of exposure to ESD at universities or schools. Without being informed about ESD during pre-service teacher education programmes conducted at universities and without being given feedback about what to do to enhance ESD in their classes, teachers may feel incompetent or insufficient when they start teaching in real classroom settings. While pre-service teacher touch upon lack of real practical experiences and limitations of micro-teaching, in-service teachers report lack of extra materials, workshops, budget, opportunities, ineffective inspection practices, and having discipline problems. Student teachers were found to be in need of more practice and guidance in terms of classroom management because they stated they don't know how to overcome discipline problems, calm down the problematic students, use their voice, and establish authority upon learners. On the other hand, in-service teachers think that inspectors do not know English and do not guide them properly to better their teaching practices. It can be said that the deficiencies in pre-service and in-service teacher education programmes could ruin integration of ESD into existing teaching policies.

\section{Discussion and Conclusion}

It can be concluded that pre-service teachers seemed to be more optimistic about the effect of contextual factors on their future preferred teaching practices while in-service teachers were found to be mostly pessimistic about it, which might result from the fact that pre-service teachers are not exposed to various school settings and learners with different characteristics. On the contrary, in-service teachers are not equipped with the necessary coping strategies to deal with work overload and solve job-related problems. Additionally, some participants touched upon the importance of possessed professional knowledge and skills to overcome context-bound problems or differences such as classroom management skills, various approaches and techniques, and colleague support. According to P.I.S.E.T. theory, ESD is affected by contextual factors in terms of personal, institutional, stakeholder-related, environmental and training-related factors. If these factors are taken into consideration in decision-making procedures, ESD can be integrated into teacher education programmes and educational success can be increased.

The study findings display certain similarities and differences with the previous findings in the relevant literature. To exemplify, the results of the study bear similarities with those of Gholami and Qurbanzada (2016) in terms of the importance and increased need of practical courses that are considered to prepare student teachers for real teaching environments and help them continue sustainability in their professional lives. In parallel 
with Pehkonen and Turner (1999), contextual factors like the school setting, administration, student profile and parental involvement were found to affect professional skills of teachers but no participant mentioned the impact of contextual factors on research skills, which could be due to their lacking research skills or work overload to cover the curriculum. Similarly, in Corte, den Broka, Kamp and Bergen (2013), context was the determining factor for teachers' research skills. However, in this study no participant mentioned the positive or negative effect of the contextual differences on their research studies. Behaviour management and lack of stakeholder support were highlighted by some participants, which is in agreement with the findings of Kilgore, Griffin, OtisWilborn and Winn (2003). Similar to Ingvarson, Beavis and Kleinhenz (2007), some participants stated that they could disregard outer factors since they were well-equipped with certain professional knowledge and skills in terms of methodology but no participant touched upon their high-level knowledge or skill in terms of content, planning and assessment, which could result from the lack of content knowledge and practical experiences for planning a lesson and assessing real students.

Mastering content knowledge or pedagogical knowledge may not necessarily pave the way for student teachers to act in line with the principles of ESD in their future classes since they could come across unexpected situations during their lessons. The microteaching activities and presentations can create consciousness to some extent but nothing can prepare them for the real classroom dynamics except for practicum. In line with the coming flow of theoretical knowledge and practical experience, the student teacher could get the opportunity to build a bridge between theory and practice, begin to set a framework regarding his/her status as a teacher candidate and question his/her skills and knowledge. Self-efficacy beliefs come into play at this point because student teachers' perceived self-efficacy beliefs undergo changes in three different lanes, namely their experiences as a language learner, as a teacher candidate and as an in-service teacher. In light of the experiences and suggestions gathered, pre-service teachers can be taught about possible future educational situations and constraints, and in-service teachers can receive training in line with these contextual differences in order to ensure sustainability in their professional lives.

Coping with the needs and expectations of educational system and dealing with contextual factors bring a unique responsibility and workload on the shoulders of teachers. Keeping the principles of ESD, policy makers and authorities give priority to its implementation at schools and teacher education programmes. Only in this way can student teachers gain consciousness about a sustainable development and in-service teachers put effort into applying it in their classrooms.

\section{References}

Ates, D., Teksöz, G., \& Ertepinar, H. (2017). Exploring the role of future perspective in predicting Turkish university students' beliefs about global climate change. Discourse and Communication for Sustainable Development, 8(1), 32-52.

Aslandağ Soylu, B., Yanpar Yelken, T., \& Külekci, M. K. (2016). Evaluating lifewide learning habits of academicians for sustainable development. Discourse and Communication for Sustainable Education, 7(2), 132-143. doi: 10.1515/dcse-2016-0021 
Barth, M., Godemann, J., Rieckmann, M., \& Stoltenberg, U. (2007). Developing key competencies for sustainable development in higher education. Journal of Sustainability in Higher Education, 8(4), 416-430.

Burns, S. N., \& Grove, S. K. (2003). Understanding nursing research. 3rd edition. Philadelphia: Saunders.

Corte, M. V., den Broka, P., Kamp, M., \& Bergen, T. (2013). Teacher research in Dutch professional development schools: Perceptions of the actual and preferred situation in terms of the context, process and outcomes of research. European Journal of Teacher Education, 36(1), 3-23.

Creswell, J. W., Plano Clark, V. L., Gutmann, M. L., \& Hanson, W. E. (2003). Advanced mixed methods research designs. In A. Tashakkori \& C. Teddlie (Eds.), Handbook of mixed methods in social and behavioral research (pp. 209-240). Thousands Oaks, Calif.: Sage.

Çoklar, A. N., \& Kabakçı Yurdakul, I. (2017). Technology Integration Experiences of Teachers. Discourse and Communication for Sustainable Education, 8(1), 19-31. de Haan, G. (2006). The BLK '21' programme in Germany: a 'Gestaltungskompetenz'based model for education for sustainable development. Environmental Education Research, 1, 19-32.

Dörnyei, Z. (2007). Research methods in applied linguistics. Quantitative, qualitative and mixed methodologies. New York: Oxford University Press.

Education, Audiovisual and Culture Executive Agency (EACEA) P9 Eurydice. (2009). Indicators on initial teacher education (extracted from Key Data on Education).

Fernet, C., Trépanier, S. G., Austin, S., \& Levesque-Côté, J. (2016). Committed, inspiring, and healthy teachers: How do school environment and motivational factors facilitate optimal functioning at career start? Teaching and Teacher Education, 59, 481-491.

Glaser, B. G., \& Strauss, A. L. (1980). The discovery of grounded theory: Strategies for qualitative research (11th ed.). New York: Aldine Publishing Company.

Gholami, J., \& Qurbanzada, I. (2016). Key stakeholders' attitudes towards teacher education programs in TEFL: a case study of Farhangian university in Iran. Journal of Teacher Education for Sustainability, 18(2), 5-20. doi: 10.1515/jtes-2016-0011

Grayson, J. L., \& Alvarez, H. K. (2008). School climate factors relating to teacher burnout: A mediator model. Teaching and Teacher Education, 24, 1349-1363.

Grossman, P., \& McDonald, M. (2008). Back to the future: Directions for research in teaching and teacher education. American Educational Research Journal, 45(1), 184-205. doi: 10.3102/0002831207312906

Hiller, K., \& Reichart, B. (2017). Motivation of civic education teachers-in-training in the field of education for sustainable development. Discourse and Communication for Sustainable Development, 8(1), 81-89.

Iliško, Dz. (2007). Teachers as agents of societal change. Journal of Teacher Education for Sustainability, 7, 14-26.

Ingvarson, L., Beavis, A., \& Kleinhenz, E. (2007). Factors affecting the impact of teacher education programmes on teacher preparedness: implications for accreditation policy. European Journal of Teacher Education, 30(4), 351-381. doi: 10.1080/ 02619760701664151 
Kilgore, K., Griffin, C., Otis-Wilborn, A., \& Winn, J. (2003). The problems of beginning special education teachers: Exploring the contextual factors influencing their work. Action in Teacher Education, 25(1), 38-47. doi: 10.1080/01626620.2003.10463291

Knoblauch, D., \& Hoy, A. W. (2008). “Maybe I can teach those kids.” The influence of contextual factors on student teachers' efficacy beliefs. Teaching and Teacher Education, 24, 166-179.

Maxwell, J. A. (1992). Understanding and validity in qualitative research. Harvard Educational Review, 62, 279-299.

Miles, M. B., \& Huberman, A. M. (1994). Qualitative data analysis. London: Sage Publication.

Naylor, D. A., Campbell-Evans, G., \& Maloney, C. (2015). Learning to teach: What do pre-service teachers report. Australian Journal of Teacher Education, 40(11), 120-136.

Pehkonen, E., \& Turner, G. (1999). Teachers' professional development: What are the key change factors for mathematics teachers? European Journal of Teacher Education, 22(2-3), 259-275.

Pipere, A. (2016). Envisioning complexity: Towards a new conceptualization of educational research for sustainability. Discourse and Communication for Sustainable Education, 7(2), 68-91. doi: 10.1515/dcse-2016-0017

Salīte, I. (2015). Searching for sustainability in teacher education and educational research: Experiences from the Baltic and Black Sea Circle Consortium for educational research. Discourse and Communication for Sustainable Education, 6, 21-29.

Sahin, E. (2016). Delving into key dimensions of ESD through analyses of a middle school science textbook. Discourse and Communication for Sustainable Education, 7(2), 34-42. doi: 10.1515/dcse-2016-0014

Schildkamp, K., \& Kuiper, W. (2010). Data-informed curriculum reform: Which data, what purposes, and promoting and hindering factors. Teaching and Teacher Education, 26, 482-496.

Strauss, A., \& Corbin, J. (Eds). (1998). Basics of qualitative research, techniques and procedures for developing grounded theory (2nd ed.). London, CA: Sage Publications.

Sundh, S. (2016). Corpus of young learners' English in the Baltic region n texts for studies on sustainable development. Discourse and Communication for Sustainable Education, 7(2), 92-104. doi: 10.1515/dcse-2016-0018

Thornberg, R. (2012). Informed grounded theory. Scandinavian Journal of Educational Research, 56(3), 243-259.

Williams, D. L., Edwards, B., \& Kuhel, K. A. (2016). Culturally responsive dispositions in prospective mathematics teachers. Discourse and Communication for Sustainable Education, 7(2), 17-33. doi: 10.1515/dcse-2016-0013

Correspondence concerning this article should be addressed to Çağla Atmaca, Department of English Language Teaching, Faculty of Education, Pamukkale University, Çamlaraltı District, University Street, Nu: 11/A, 20070, Kınıklı, Denizli, Turkey. Email: caglaatmaca90@gmail.com 